\title{
Genetic Diversity of Remaining Populations of Mangaba (Hancornia speciosa Gomes) in Restingas of Brazil
}

\author{
Ana Veruska Cruz da Silva ${ }^{1}$, Julie Anne Espíndola Amorim², Marília Freitas de Vasconcelos Melo ${ }^{3}$, \\ Ana da Silva Ledo ${ }^{1} \&$ Allivia Rouse Carregosa Rabbani ${ }^{4}$ \\ ${ }^{1}$ Embrapa Coastal Tablelands, Aracaju, Sergipe, Brazil \\ ${ }^{2}$ State University of São Paulo 'Júlio de Mesquita Filho', Jaboticabal, São Paulo, Brazil \\ 3 State University of São Paulo ‘Júlio de Mesquita Filho', Botucatu, São Paulo, Brazil \\ ${ }^{4}$ Federal Institute of Bahia, Porto Seguro, Bahia, Brazil \\ Correspondence: Ana Veruska Cruz da Silva, Embrapa Coastal Tablelands, Av. Beira mar, 3250, 49025040, \\ Aracaju, SE, Brazil. Tel: 55-79-4009-1362. E-mail: ana.veruska@embrapa.br
}

Received: October 8, 2016

Accepted: November 26, 2016

Online Published: January 15, 2017

doi:10.5539/jas.v9n2p46

URL: http://dx.doi.org/10.5539/jas.v9n2p46

\begin{abstract}
Mangaba (Hancornia speciosa Gomes) is a fruit species that is native to Brazil, and has social, economic and cultural importance. Knowledge of the genetic relationships between the remaining populations is essential in order to promote conservation strategies for these genetic resources. In the present study, it was evaluated the genetic diversity of 35 individuals from three remaining restingas areas in the states of Ceará (Iguape and Cascavel) and Pernambuco (Tamandaré), located in the Brazilian Northeast. Nine ISSR primers were used to determine the genetic variability. Sixty-one fully polymorphic fragments $(100 \%)$ were generated. The largest (10) and smallest (5) number of fragments were obtained with the primers HB14 and HB12, respectively. The Shannon index $(\mathrm{I}=0.40)$, the genetic diversity $(\mathrm{H}=0.30)$, and the percentage of polymorphic loci $(\% \mathrm{P}=$ $73.77 \%$ ) were also estimated. Both the methods of UPGMA and the Principal Coordinates Analysis (PCoA) clustered individuals according to their place of origin. Genetic divergence was greater within population (64\%) than between them (36\%). This may indicate a strong genetic structure, i.e., the gene flow rate between populations is low, favoring inbreeding. ISSR markers were efficient for the analysis of genetic diversity, for the identification of clusters, and for the estimation of the genetic distance between and within populations.
\end{abstract}

Keywords: Hancornia speciosa Gomes, Apocynaceae, genetic variability, conservation

\section{Introduction}

Hancornia speciosa Gomes (Apocynaceae family) is a fruit species that is native to Brazil, popularly known as mangaba. It naturally occurs in coastal tablelands in in the Brazilian Northeast, and in the Brazilian Central-Western and Northern Cerrado. The fruit is typically tropical and highly appreciated by consumers due to its organoleptic characteristics and nutritional value. It is currently found in the list of endangered species, and has aroused interest for studies which could result in conservation strategies of this genetic resource.

Several factors, such as forest fragmentation, tourism, and increase in areas cultivated with coconut, pasture, and sugarcane have contributed to the significant reduction of naturally occurring growing areas. Therefore, studies examining the genetic diversity and structure of remnant mangaba populations are fundamental for establishing conservation strategies for germplasm and species preservation (Amorim et al., 2015).

Information on the development and genetic variation of native species are crucial, since domestication and incorporation of these species in regional production systems, and the development of efficient conservation strategies are closely related to the knowledge of the magnitude and of the distribution of genetic variability in natural populations. Molecular characterization is a form of diversity evaluation which allows, from genetic markers, regardless of environmental interference, inferring the diversity degree among individuals and populations (Costa et al., 2011).

Due to the economic potential of the species, several researches have been carried out in all areas of its occurrence. Mangaba Active Germplasm Bank is found in the state of Sergipe, with 271 individuals from 19 
natural populations representative of eight states. Costa et al. (2011) evaluated the diversity of this BAG in its initial phase by means of RAPD markers (Random Amplified Polymorphic DNA), when there were only 55 genotypes, and observed low genetic similarity.

ISSR Molecular markers (Inter Simple Sequence Repeat) are widely used in genetic diversity studies. It is a simple, effective technique, which has high reproducibility and produces high polymorphism rates (Reddy et al. 2002). Most part of the published studies present results regarding genetic diversity in native populations, such as that of Moura et al. (2005) with populations of the Cerrado Biome, using RAPD; Costa et al. (2015) with populations from Rio Grande Norte, using ISSR markers; and Amorim et al. (2015) with populations from Ceará, Pernambuco and Sergipe, using microsatellites. Jimenez et al. (2015) characterized 38 individuals using ISSR markers from the coast of Pernambuco.

This study was carried out in order to know the genetic diversity of remaining restinga's areas of mangaba in the Northeast of Brazil using ISSR markers, aiming the genetic conservation of the species, seed collection for recovery of degraded areas and future breeding program.

\section{Method}

It was used 35 mangaba individuals collected in three remaining populations obtained in the cities of Iguape (Tapera, Ceará), Jacarecoara (Cascavel, Ceará), and Tamandaré (Pernambuco) (Table 1).

Table 1. Identification, geographical location and sample size of three populations of $H$. speciosa Gomes

\begin{tabular}{lll}
\hline Population & Geographical coordinates & N. individuals \\
\hline Cascavel, Jacarecoara (CE) & $4^{\circ} 07^{\prime} 10^{\prime \prime}$ S e $38^{\circ} 10^{\prime} 34^{\prime \prime} \mathrm{O}$ & 14 \\
Iguape, Tapera (CE) & $3^{\circ} 56^{\prime} 20^{\prime \prime} \mathrm{S}$ e $38^{\circ} 20^{\prime} 18^{\prime \prime} \mathrm{O}$ & 06 \\
Tamandaré (PE) & $8^{\circ} 43^{\prime} 50^{\prime \prime} \mathrm{S}$ e $35^{\circ} 6^{\prime} 10^{\prime \prime} \mathrm{O}$ & 15 \\
\hline Total & & 35 \\
\hline
\end{tabular}

DNA extraction was based on the standard CTAB protocol (Costa et al., 2011). Quantification was conducted using a NanoDrop 2000c (Thermo Scientific) spectrophotometer at the ranges of 260-280 nm; while purity was calculated by the OD260/OD280 ratio. The evaluation of DNA quality was performed by electrophoresis on 1\% agarose gel, and visualized in the Gel Doc L-pix HE (Loccus Biotechnology, Brazil) photo documentation device. After the measurement, samples were diluted in TE solution for the concentration of $25 \mathrm{ng} / \mu \mathrm{L}$, and stored at $-20{ }^{\circ} \mathrm{C}$ for subsequent use in ISSR reactions.

After preliminary tests using 28 ISSR primers, nine of them were selected (Table 2). PCR (polymerase chain reaction) consisted of $2 \mu \mathrm{L}$ genomic DNA $(25 \mathrm{ng} / \mu \mathrm{L}), 1 \mu \mathrm{L}$ of each primer $(5 \mathrm{mM}), 14.4 \mu \mathrm{L}$ sterile water MilQ, $2 \mu \mathrm{L} 10 \mathrm{X}$ reaction buffer with $\mathrm{MgCl}_{2}$ (Promega, Madison, South Dakota, EUA), $0.4 \mu \mathrm{L} \mathrm{dNTP}(10 \mathrm{nM})$, and 0.2 Taq polymerase $(5 \mathrm{U} / \mu \mathrm{L})$, with final volume of $20 \mu \mathrm{L}$ reaction.

Amplification was carried out in a thermocycler (Axygen Maxygene ${ }^{\circledR}$, Union City, EUA). Samples were subjected to denaturation at $95{ }^{\circ} \mathrm{C}$ for five min, followed by 45 amplification cycles. At each cycle, samples underwent denaturation at $94{ }^{\circ} \mathrm{C}$ for $1 \mathrm{~min}$, annealing at different temperatures for $45 \mathrm{~s}$, and extension at $72{ }^{\circ} \mathrm{C}$ for two min, and a final extension at $72{ }^{\circ} \mathrm{C}$ for $10 \mathrm{~min}$, followed by cooling at $10^{\circ} \mathrm{C}$.

Fragments were visualized on $2 \%$ agarose (1x TBE $89 \mathrm{mM}$, Tris $89 \mathrm{mM}$, boric acid $2.5 \mathrm{mM}$, EDTA pH 8.3 ) in a horizontal electrophoresis system performed at $100 \mathrm{~V}$ for $90 \mathrm{~min}$. The gel was stained with ethidium bromide solution $\left(5 \mathrm{mg} \cdot \mathrm{mL}^{-1}\right)$ for $30 \mathrm{~min}$. Amplification products were visualized under UV light using the Gel doc (Loccus Biotecnologia, Cotia, SP) photo documentation device.

In the evaluation of the gels, the presence (1) and the absence (0) of bands were used for the construction of a binary matrix and subsequent statistical analyses. The polymorphic information content (PIC) was calculated according to Ghislain et al. (1999), and the marker index (MI) was determined as described by Zhao et al. (2007). The Shannon index - I (Brown \& Weir, 1983), the genetic diversity - H (Lynch \& Milligan, 1994; Maguire et al., 2002), and the analysis of molecular variance - AMOVA (Michalakis \& Excoffier, 1996) were estimated using the Genalex v.6.3.

The estimate of the genetic similarity between each pair of individuals was calculated by the Jaccard coefficient, using the Free Tree software (Pavlicek et al., 1999), and its simplified representation was obtained by the dendrograms constructed by Unweighted Pair-Group Method with Arithmetic Mean (UPGMA) based on the 
Treeview software (Page, 1996). In order to analyze the robustness of each clustering, analysis was performed by bootstrap resampling using the Treeview software (Page, 1996), at 10,000 x. The principal coordinates analysis (PCA) was performed using the Genalex v.6.3 software, based on the Jaccard coefficient (Peakall \& Smouse, 2006).

\section{Results}

Nine primers (Table 2) generated 61 fully polymorphic fragments. The largest (10) and lowest (5) number of fragments were obtained with the primers HB14 and HB12 primers, respectively. The value of PIC was 0.65 (0.43 to 0.78$)$, and MI had mean of 4.42 (2.56 to 7.33 ).

Table 2. Number of polymorphic fragments (NPF), polymorphic information content (PIC), and marker index (MI) of 37 individuals of Hancornia speciosa obtained from remaining population from the states of Ceará and Pernambuco

\begin{tabular}{lllll}
\hline Locus & Sequence & NPF & PIC & MI \\
\hline $844 \mathrm{~A}$ & CTCTCTCTCTCTC & 6 & 0,43 & 2,56 \\
$844 \mathrm{~B}$ & CTCTCTCTCTCTCTCTGC & 7 & 0,59 & 4,12 \\
$17899 \mathrm{~B}$ & CACACACACACAGG & 7 & 0,78 & 5,48 \\
HB10 & GAGAGAGAGAGACC & 8 & 0,67 & 5,35 \\
HB12 & CACCACCACGC & 5 & 0,66 & 3,31 \\
HB14 & CTCCTCCTCGC & 10 & 0,73 & 7,33 \\
HB15 & GTGGTGGTGGC & 4 & 0,72 & 2,87 \\
810 & GAGAGAGAGAGAGAGAT & 7 & 0,74 & 5,15 \\
841 & GAGAGAGAGAGAGAGATC & 7 & 0,52 & 3,62 \\
\hline Total & & 61 & 0,65 & 4,42 \\
\hline
\end{tabular}

The Shannon index ranged from 0 to 1 , and the closer to 1 , the greater is the genetic diversity (Estopa et al., 2006). In the populations studied, this value ranged from 0.37 to 0.44 (Table 3), which allowed to infer that the analyzed populations have genetic diversity reserves. The mean genetic diversity for the different areas was 0.28 . The percentage of polymorphic loci was higher in the population CE1 (Cascavel, CE), with $85.25 \%$, followed by PE (Tamandaré, PE), and CE2 (Iguape, CE), with 77.05 and 59.02\%, respectively.

Table 3. Shannon Index (I), Genetic Diversity (H) and percentage of polymorphic loci (P\%) in natural populations of Hancornia speciosa Gomes found in remaining populations from the states of Ceará and Pernambuco, using ISSR markers

\begin{tabular}{llll}
\hline Pop & $\mathrm{I}$ & $\mathrm{H}$ & $\mathrm{P} \%$ \\
\hline CE1 & $0.44( \pm 0.03)$ & $0.30( \pm 0.02)$ & $85.25 \%$ \\
CE2 & $0.37( \pm 0.04)$ & $0.26( \pm 0.03)$ & $59.02 \%$ \\
PE & $0.40( \pm 0.04)$ & $0.27( \pm 0.03)$ & $77.05 \%$ \\
\hline Total & $0.40( \pm 0.02)$ & $0.28( \pm 0.01)$ & $73.77 \%$ \\
\hline
\end{tabular}

From the AMOVA (Table 4) it was possible to observe the pattern of genetic variability distribution (PhiPT 0.36 *** $\mathrm{p}<0.001)$. Results showed that genetic diversity within populations was greater $(64 \%)$ than between them $(36 \%)$.

Table 4. Analysis of molecular variance (AMOVA) between and within different locations of accessions of Hancornia speciosa Gomes

\begin{tabular}{lllll}
\hline & df & Variance & Variantion (\%) & PhiPT \\
\hline Among & 2 & 4.6812 & 36 & $0.364 * * *$ \\
Within & 34 & 8.395 & 64 & \\
\hline Total & 36 & 13.207 & $100 \%$ & \\
\hline
\end{tabular}

Note. df: degrees of freedom; $* * * \mathrm{p}<0.001$. 
According to the dendrogram, it was observed the formation of three main clusters: one consisting of the individual CE1-12 (CI); one consisting of the individuals CE1-11 and CE1-4 (CIII); and another consisting of the other individuals (CII), which can be subdivided into four subclusters. It was evident that the place of origin directly influenced the clusters. All individuals originated from Pernambuco were close, as well as CE2 and CE1. The dendrogram analysis also suggests that individuals from Tamandare (PE) are genetically closer to those from Iguape (CE2) (Figure 1).

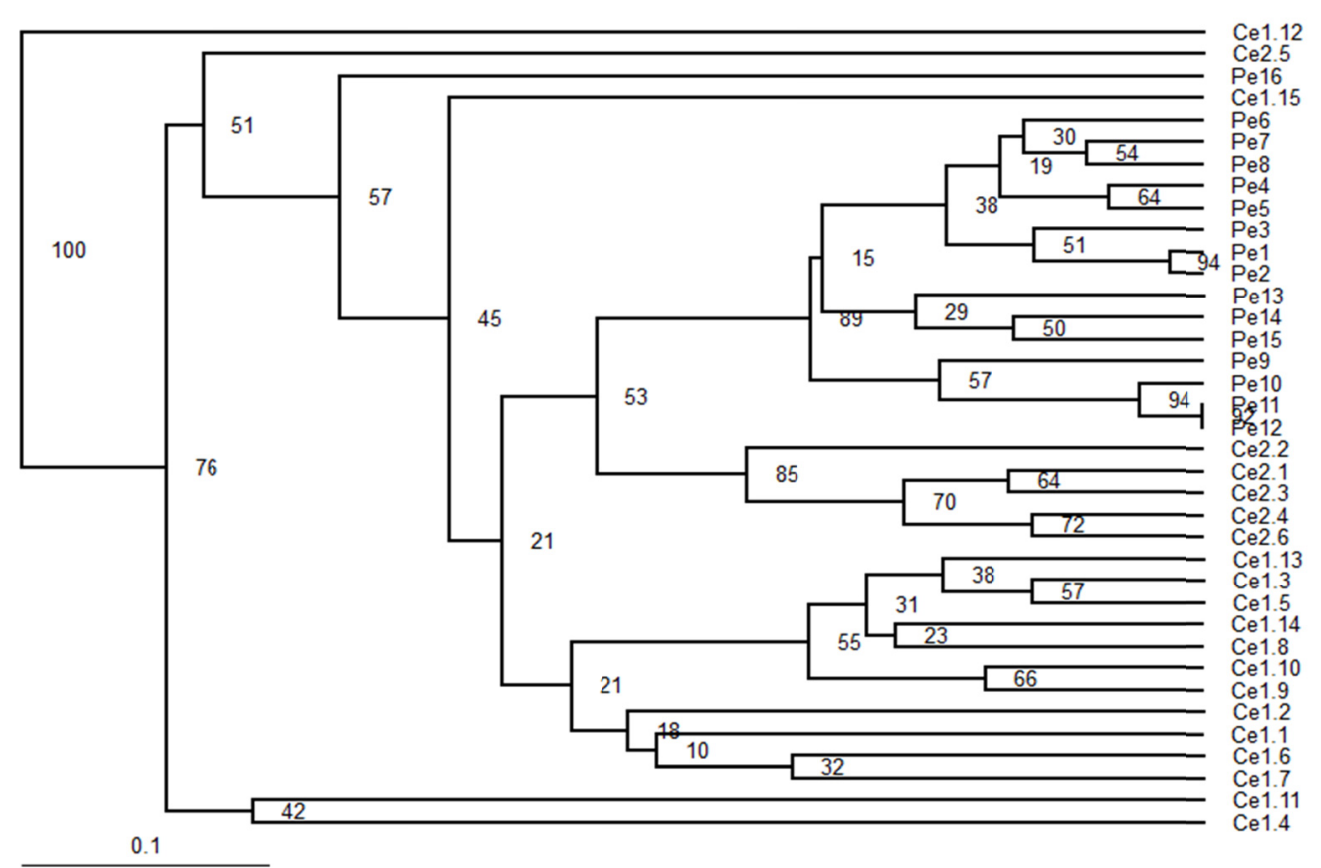

Figure 1. Similarity dendrogram by the Jaccard Coefficient, UPGMA (Unweighted Pair-Group Method with Arithmetic Mean) and bootstraps at 10,000x for mangaba remaining populations (Hancornia speciosa Gomes) evaluated by ISSR markers (CE1 - Cascavel; CE2 - Iguape; PE - Tamandaré)

Analysis of the main coordinates - PCoA (Figure 2) indicated that individuals formed four clusters, three of them separated by the origin. ISSRs efficiency was confirmed since the percentage of the variation accumulated in the first two axes was $66.76 \%$, indicating genetic diversity between the individuals studied. Similar to the dendrogram analysis, individuals were clustered according to their origin. PE1 and CE2 are close to each other, as well as the individuals CE1-11 and CE1-14; CE1-12 and CE2-5, as shown in Figure 1. 


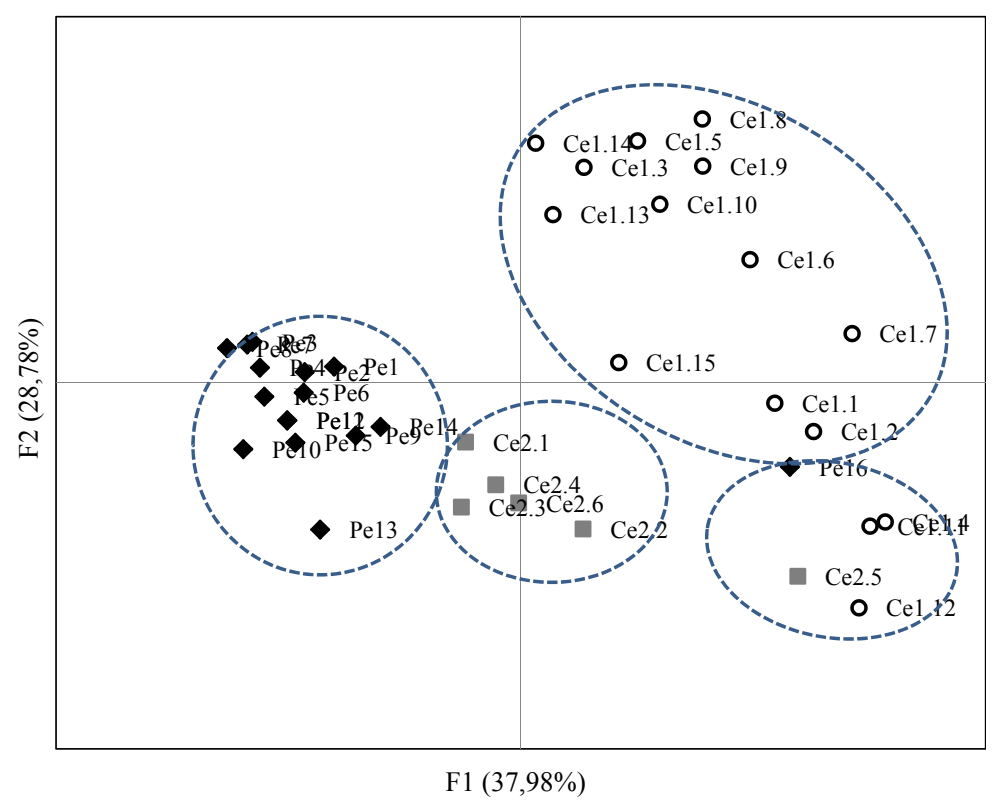

Figure 2. Principal Coordinates Analysis (PCoA) for remaining species of mangaba (Hancornia speciosa Gomes) evaluated by ISSR markers (CE1 - Cascavel; CE2 - Iguape; PE - Tamandaré)

\section{Discussion}

Selection of the characters of interest together with the genetic diversity data are important for the management of a germplasm bank, and they also assist in breeding programs. Knowledge of the genetic variability available for selection of superior plants is fundamental. The genetic relationships between remaining populations of mangaba will be important for the selection of individuals to be included in the germplasm bank, as well as for determining conservation strategies of these scarce genetic resources.

Regarding the number of polymorphic loci, we can check the work realized by Jimenez et al. (2015), where through six primers ISSR in mangaba, obtained a larger number of fragments (93), ranging from 9 to 21 fragments per primer. However, polymorphism percentage was lower $(89.25 \%)$ than the $100 \%$ value observed in this study. The ten RAPD primers reported in mangaba by Silva et al. (2012) resulted in $85 \%$ polymorphism in the 60 amplified fragments. Fragments generated in this study can be considered very informative, unlike the results reported for mangaba germplasm (Costa et al., 2011) and for natural populations found in the state of Sergipe (Silva et al., 2012).

This index (I) is a useful tool for population analysis when using dominant markers, such as ISSRs. The Shannon index makes the effects of distortion caused by the inability of heterozygous loci detection be relatively neutral. The values obtained in this study are consistent with those reported by Silva et al. (2012) in natural population of mangaba from the state of Sergipe. In other species, the values of 'I' was lower, such as in cupuaçu - Theobroma gradiflorum (0.15-0.17) (Silva et al., 2016) and genipap - Genipa americana L. (mean value of 0.21) (Silva et al., 2014).

The value found for the genetic diversity is close to those found by Tambarussi et al. (2008) in Piptadenia gonoacantha Mart. $(\mathrm{H}=0.29)$, and by Gois et al. (2014) in natural populations of Ziziphus joazeiro Mart. $(\mathrm{H}=$ 0.36). Research with Theobroma speciosum showed values well below - 0.076 (Gustina et al., 2014). However, in mangaba Silva et al. (2012) found mean value of 0.35. Under natural conditions, the value of ' $\mathrm{H}$ ' is always different from zero, since individuals are susceptible to incorporation of new alleles by cross, even in small populations or fragments, in addition to losses due to genetic drift (Silva et al., 2014).

The lowest level of percentage of polimorfic locus in CE2 indicates that this population is isolated. Heterozygosity loss is usually associated with random events of colonization and genetic drift (Pinto \& Carvalho, 2004). According to the results, the species presents genetic diversity in the evaluated remaining populations, which was proven by the value of total heterozygosity observed $(0.28)$.

The greater genetic diversity within than between populations may indicate a strong genetic structure, i.e., the gene flow rate between populations is low, favoring inbreeding (Silva et al., 2014). Allogamous species with 
outcrossing generally present low diversity levels between populations and high differentiation within them (Sun et al., 2006).

The characterization of the genetic relationships between remaining populations of mangaba originated from these two states is valuable data, since the areas of occurrence have been almost totally devastated. Therefore, it is necessary to stablish conservation strategies for these genetic resources, since these genotypes can be used both for in situ and ex situ conservation, as well as for breeding programs.

In this work, the use of ISSR markers allowed characterizing and measuring the high genetic diversity of remaining populations of mangaba found in the states of Ceará and Pernambuco, northeastern Brazil. Genotypes were clustered according to their origin, and have potential for increments of collections aimed at conservation.

\section{References}

Amorim, J. A. E., Mata, L. R., Ledo, A. S., Azevedo, V. C. N., \& Silva, A. V. C. (2015). Diversity and genetic structure of mangaba remnants in states of northeastern Brazil. Genetics and Molecular Research, 14, 823-833. https://doi.org/10.4238/2015.February.2.7

Costa, D., Vieira, F. A., Fajardo, C. G., \& Chagas, K. P. T. (2015). Genetic diversity and issr initiators selection in a natural population of mangaba (Hancornia speciosa Gomes) (Apocynaceae). Revista Brasileira de Fruticultura, 37, 970-976. https://doi.org/10.1590/0100-2945-246/14

Costa, T. S., Silva, A.V. C., Ledo, A. S., Santos, A. R. F., \& Silva Júnior, J. F. (2011). Genetic diversity of accessions of the mangaba germplasm bank in Sergipe, Brazil. Pesquisa Agropecuária Brasileira, 46, 499-508. https://doi.org/10.1590/S0100-204X2011000500007

Estopa, R. A., Souza, A. M., Moura, M. C. O., Botrel, M. C. G., Mendonça, E. G., Carvalho, D., et al. (2006). Genetic diversity in natural populations of candeia(Eremanthus erythropappus (DC.) MacLeish). Scientia Forestalis, 70, 97-106. Retrieved from http://www.ipef.br/publicacoes/scientia/nr70/cap10.pdf

Ghislain, M., Zhang, D., Fajardo, D., Huamán, Z., \& Hijmans, R. J. (1999). Marker assisted sampling of the cultivated Andean potato Solanum phureja collections using RAPD markers. Genetic Resources and Crop Evolution, 46, 547. https://doi.org/10.1023/A:1008724007888

Gois, I. B., Ferreira, R. A., Mann, R. S., Pantaleão, S. M., Gois, C. B., \& Oliveira, R. S. C. (2014). Genetic variability in natural populations of Ziziphus joazeiro Mart., by RAPD molecular markers. Revista Árvore, 38, 621-630. https://doi.org/10.1590/S0100-67622014000400005

Gustina, L. D., Luz, L. N., Vieira, F. S., Rossi, F. S., Soares-Lopes, C. R. A., Pereira, T. N. S., \& Rossi, A. A. B. (2014). Population structure and genetic diversity in natural populations of Theobroma speciosum Willd. ex Spreng (Malvaceae). Genetics and Molecular Research, 13, 47-53. https://doi.org/10.4238/2014. february. 14.5

Jimenez, H. J., Martins, L. S. S., Montarroyos, A. V. V., Silva Junior, J. F., Alzate-Marin, A. L., \& Moraes Filho, R. M. (2015). Genetic diversity of the Neotropical tree Hancornia speciosa Gomes in natural populations in Northeastern Brazil. Genetics and Molecular Research, 14, 17749-17757. https://doi.org/10.4238/2015. December.21.48

Lynch, M., \& Milligan, B. G. (1994). Analysis of population genetic structure with RAPD markers. Molecular Ecology, 3, 91-99. https://doi.org/10.1111/j.1365-294X.1994.tb00109.x

Maguire, T. L., Peakall, R., \& Saeger, P. (2002). Comparative analysis of genetic diversity in the mangrove species Avicennia marina (Forsk.) Vierh (Avicenniaceae) detected by AFLPs and SSRs. Theoretical and Applied Genetics, 104, 388-398. https://doi.org/10.1007/s001220100724

Michalakis, Y., \& Excoffier, L. (1996). A generic estimation of population subdivision using distances between alleles with special reference for microsatellite loci. Genetics, 142, 1061-1064. Retrieved from http://www.genetics.org/content/142/3/1061.

Moura, N. F., Chaves L. J., Vencovsky, R., Zucchi, M. I., Pinheiro, J. B., Morais, L. K., \& Moura, M. F. (2005). Selection of RAPD markers to study genetic structure of Hancornia speciosa Gomes. Bioscience Journal, 21, 119-125. Retrieved from http://www.seer.ufu.br/index.php/biosciencejournal/article/viewFile/6615/4348

Page, R. D. M. (1996). TreeView: An application to display phylogenetic trees on personal computers. Computer Applications in the Bioscience, 12, 357-358.

Pavlicek, A., Hrda, S., \& Flegr, J. (1999). Free-Tree: Freeware program for construction of phylogenetic trees on the basis of distance data and bootstrap/jackknife analysis of the tree robustness. Application in the RAPD 
analysis of genus Frenkelia. Folia Biologica, 45, 97-99. Retrieved from https://www.researchgate.net/ publication $/ 12585108$

Peakall, R., \& Smouse, P. E. (2006). Genalex6: Genetic analysis in Excel. Population genetic software for teaching and research. Molecular Ecology Notes, 6, 288-295. https://doi.org/10.1111/j.1471-8286.2005. 01155.x

Pinto, S. I. C., \& Carvalho, D. (2004). Genetic structure in populations of pindaíba (Xylopia brasiliensis Sprengel) by isozymes. Revista Brasileira de Botânica, 27(3), 597-605. https://doi.org/10.1590/S0100-8404 2004000300019

Reddy P. M., Sarla, N., \& Siddiq, E. A. (2002). Inter simple sequence repeat (ISSR) polymorphism and its application in plant breeding. Euphytica, 128, 9-17. https://doi.org/10.1023/A:1020691618797

Silva, A. V. C., Freire, K. C. S., Ledo, A. S., \& Rabbani, A. R. C. (2014). Diversity and genetic structure of jenipapo (Genipa Americana L.) brazilian. Scientia Agricola, 71, 345-355. https://doi.org/10.1590/01039016-2014-0038

Silva, A. V. C., Santos, A. R. F., Wickert, E., Silva Júnior, J. F., \& Costa, T. S. (2012). Divergência genética entre acessos de mangabeira (Hancornia speciosa Gomes). Revista Brasileira de Ciências Agrárias, 6, 572-578. https://doi.org/10.5039/agraria.v6i4a943

Silva, B. M., Rossi, A. A. B., Dardengo, J. F. E., Araújo, V. A. A. C., Rossi, F. S., Oliveira, L. O., \& Clarindo, W. R. (2016). Genetic diversity estimated using inter-simple sequence repeat markers in commercial crops of cupuassu tree. Ciência rural, 46, 108-113. https://doi.org/10.1590/0103-8478cr20141634

Sun, K., Chen, W., Ma, R., Chen, X., Li, A., \& Ge, S. (2006). Genetic variation in Hippophaerhamnoidesssp. Sinensis (Elaeagnaceae) revealed by RAPD markers. Biochemical Genetics, 44, 186-197. https://doi.org/10.1007/s10528-006-9025-2

Tambarussi, E. V., Mori, E. S., Zimback, L., Mori, N. T., Pinto, C. S., \& Fernandes, K. H. P. (2008). Genetic structure of Piptadenia gonoacantha (Mart.) Macbr. populations through molecular markers RAPD. Revista Cientifica Eletrônica de Engenharia Florestal, 7, 1-15. Retrieved from http://faef.revista.inf.br/imagens arquivos/arquivos_destaque/llb0mWFbe71kwD5_2013-4-29-9-36-14.pdf

Zhao, K., Zhou, M. Q., \& Chen, L. Q. (2007). Genetic diversity and discrimination of Chimonanthus praecox (L.) link germplasm using ISSR and RAPD markers. HortScience, 42, 1144-1148. Retrieved from http://hortsci.ashspublications.org/content/42/5/1144.full.pdf + html

\section{Copyrights}

Copyright for this article is retained by the author(s), with first publication rights granted to the journal.

This is an open-access article distributed under the terms and conditions of the Creative Commons Attribution license (http://creativecommons.org/licenses/by/4.0/). 